\title{
Ecological responsibility of tourism
}

\author{
Abdulwahab Tenish \\ Phd,Candidate \\ DOI: 10.29322/IJSRP.10.11.2020.p10746 \\ http://dx.doi.org/10.29322/IJSRP.10.11.2020.p10746
}

\begin{abstract}
As it becomes obvious that ecotourism is a growing market, governments around the world are showing a rising interest in drawing attention to ecotourism as part of their tourism development program. Ecotourism implies conscientious travel in nature while preserving the environment and improving the living standards of the local population and is one of the most dynamic segments of the international travel industry.
\end{abstract}

Index Terms- Ecotourism, Preservation and protaction, sustainable development

\section{INTRODUCTION}

$\mathrm{T}$ oday's increased interest in sustainable tourism and ecotourism is the result, among other things, of increasing public awareness of the quality of protected areas and the impacts of tourism. The main role of the ecologically protected area as a tourist destination (which is today one of the most common ecotourism destinations) is to ensure the quality of guests and the long-term existence of the local population.

Ecology has become equaly a trend and an essential need of modern society. Return to pure untouched nature, organic food, use of natural materials, renewable energy sources, etc. is a world movement that is reflected in tourism as an integral part of society. There is almost no country in the world that does not have at least one national park, and there is also almost no country that, to a greater or lesser extent, does not improve the development of tourism.

Preservation and protaction of these areas requires large investments, which governments cannot fully service from budget funds, so the management of these areas provides the necessary financial resources through the implementation of commercial activities such as tourism. Numerous researches show that the highest growth rate from year to year is recorded by the types of tourism related to staying in pure untouched nature, with engaging in some kind of recreation or extreme sports. New exotic destinations are being sought to be discovered and explored. All this indicates that the quality and attractiveness of the natural environment form the basis of the economy in tourism.

\footnotetext{
${ }^{1}$ Bakić, O., (1993). Marketing menadžment turističke destinacije, Ekonomski fakultet, Beograd

${ }^{2}$ World Tourist Organization, (2015), Voluntary Initiatives in Sustainable Tourism: Worldwide inventory and comparative analysis
}

This publication is licensed under Creative Commons Attribution CC BY.

http://dx.doi.org/10.29322/IJSRP.10.11.2020.p10746

\section{NOVELTIES IN THE GLOBAL TOURISM MARKET}

Tourism has begun to transform from a "hard" to a "soft" form, becoming more humane and more individual-oriented. On this track, different types of tourism are emphasized, e.g. urban, cultural, rural, nautical, congress, religious, ecotourism, adventure, etc. To create a layered and transparent tourist offer as required by modern tourism, just one striking tourist attraction is no longer enough, such as a warm sea or an impressive mountain, which in "mass" tourism is marked as the primary tourist area. Studying the professional literature, we find that many authors have different views on the importance of certain tourist megatrends for the development of this industry in the future.

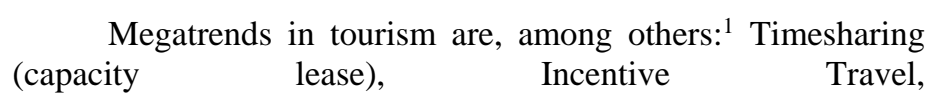
Fast food business, Theme Parks.

The World Tourism Organization - WTO, highlights five megatrends in tourism ${ }^{2}$ : ecotourism, cultural tourism, thematic tourism, cruises.

Common to all classifications is that as motives for tourist travel in the foreground emphasize fun, excitement and gaining new experiences in the natural environment. New exotic destinations are being sought to be discovered and explored. As a rule, the population that prefers these types of tourism is richer, has a higher education, great readiness to undertake travel and is a better consumer than the average tourist, so we can talk about elite tourism because of all that. Such tourist trends largely correspond to protected areas. Knowing these trends, the management of protected areas has the opportunity to put care and efforts to protect nature in the foreground of communication with visitors. It should be emphasized that every visitor and money that spends a new step towards long-term and sustainable development of the area. $^{3}$ Accordingly, such regions should use their industrial underdevelopment to attract tourists to their area who want to visit untouched natural areas. However, the arrival of such tourists in these destinations requires at least minimal infrastructure, which many regions still do not have.

\footnotetext{
${ }^{3}$ Vujović S., Cvijanović D., Štetić S., (2012), Destinacijski concept razvoja turizma, Monografija, Institut za ekonomiku poljoprivrede, Beograd
} 
For many destinations, tourists spend on accommodation, food and drink, local traffic, entertainment, shopping, etc. are an important pillar of their economies. As the economic gap between developed and underdeveloped regions deepens, tourism seeks a way out of the vicious circle of underdevelopment and poverty. Many developing countries have turned to tourism as a way of acquiring the financial resources necessary for economic growth, employment and development. Tourism in these countries has emerged as a relatively new activity that has achieved significant results in a short time.

\section{ECOTOURISM AS A MEANS OF PROTECTING NATURAL RESOURCES}

In response to the forms and phenomena of mass tourism, which lead to pollution, endangerment of natural values, exceeding the reception capacities of tourist destinations, at the end of the XX century, selective forms of tourism appeared as an alternative to mass tourism. One of the most important forms of selective tourism is certainly ecotourism.

Monitoring of the interplay between the development of large tourist centers and protected areas, coastal belts and green areas must be done continuously in order to contribute to finding a way to establish a harmonious and functional environment in which local people will have favorable living and working conditions while tourists can continue to consumption, which is the ultimate goal of the travel industry. From a socio-economic, environmental and planning point of view, care for the environment is justifiably growing today, so an integral part of urban policies for more than twenty years is the concept of sustainable development. they are not always fully accepted. ${ }^{4}$

Ecotourism has become a potential alternative to destructive industries in Latin America, such as logging, oil drilling, mining, and other industries that extract natural resources. ${ }^{5}$ People are starting to look for more adventure and ecofriendly ways to travel. In addition, developing countries have begun to see the disadvantages and negative consequences of traditional tourism as a development strategy. The situation in Africa is somewhat different from the situation in Latin America.

Ecotourism in East Africa has become popular as an alternative to the failed system of protective wildlife management, which has been reduced to separating the local population from national parks. This approach emerged as a reaction to the poaching of elephants and rhinos. Scientists and officials of national parks believed that the only way to protect these, as well as other, wild animals, is to provide a financial stimulus to parks, preservation of wildlife and tourism. ${ }^{6}$

If we compare the features of eco-tourism and the principles of environmental protection, it becomes clear that ecotourism is fully in line with the concept and goals of achieving high quality environment. Ecotourism has also proven to be one of the best mechanisms for providing financial resources for the maintenance of protected areas. This has been shown primarily in

\footnotetext{
${ }^{4}$ Čekrlija Saša, (2017), Ekoturizam i održivo upravljanje resursima, SVAROG br. 14., DOI 10.7251/SVA1714227C ${ }^{5}$ Honey, M. (1999), Ecotourism and Sustainable Development: Who Owns Paradise?, Island Press
}

less developed countries where the main resources are precisely in the field of biodiversity and where their biological and cultural diversity represents ecotourism potential.

It is clear that ecotourism in these countries is considered not only as an activity dedicated to financing environmental protection, but also as a way to improve the country's economy by attracting more tourists. The goal of ecotourism in such business ventures is not to destroy natural resources but to provide support for their protection. Ecotourism offers a sustainable alternative to making money and at the same time works to preserve irreplaceable natural resources. Ecotourism seems to continue to flourish around the world, and foreign tourists will still want to travel to countries that care about the environment. Valuable national treasures are often sacrificed under the slogan of ecotourism, due to greed and the desire for quick earnings, without taking into account the needs of the generations to come. To avoid this, it is necessary to apply international standards in this area. It is often believed that in underdeveloped areas, with small investments, ecotourism can develop quickly and provide large incomes and well-being. However, not every underdeveloped area may always be an ecologically interesting area. Also, an undeveloped area is not always a clean and unpolluted area. Any undeveloped area without built infrastructure and built legislation and its firm application is not an area for ecotourism, because mass visits of guests are not ecotourism. Environmentally sensitive consumers are increasingly aware of the harmful effects that tourism has on the area and are increasingly interested in travel that will have minimal adverse effects on the natural environment. Care for the preservation of air, water, flora and fauna, space, etc. today it is more and more present among tourist representatives and tourists themselves. Ecotourism is a specific form of tourism in which ecologically conscious individuals and groups participate, who by their actions on the environment try to reduce the effects created by the so-called. mass tourism. Unlike types of tourism that are only focused on destinations in nature, which are essentially a simple trip to areas with beautiful nature, ecotourism benefits the local population in environmental, cultural and economic terms.

\section{ECOTOURISM SUSTAINABILITY CRITERIA}

The criteria necessary for the development of ecotourism according to Ross and Wall (1999) are $^{7}$ :

1. Preservation of biodiversity and cultural diversity, by achieving a minimal impact on the natural resources of protected areas.

2. Generating sustainable and legal income for the benefit of local communities.

3. Involvement of local communities, ecotourists, tour operators and government institutions in planning and development processes.

4. Increasing environmental and cultural knowledge through respect for local traditions and culture.

\footnotetext{
${ }^{6}$ Honey, M. (1999), Ecotourism and Sustainable Development: Who Owns Paradise?, Island Press

${ }^{7}$ Ross S., Wall G. (1999). Evaluating ecotourism: The case of North Sulawesi, Indonesia, Tourism Management, 20, 673-682.
} 
5. Generation of revenues intended for the preservation of protected areas.

6. Teaching shareholders about their role in the nature conservation process.

In the field of sustainable development, everyone must cooperate, both state and local authorities, as well as entrepreneurs, private individuals, local residents and visitors. It is necessary to edit and monitor the system of indicators. All participants in sustainable tourism development must be permanently educated. The consequences of the activities of individual companies must be visible to visitors, because otherwise the interest of companies in investing in the field of environmental protection cannot be seen. It is also necessary to enable information about that to reach the visitors. The visitor will look for ecological, ie the best products for the environment in the tourist destination, which will bring economic, ecological and socio-cultural benefits to the tourist workers in the tourist destination. ${ }^{8}$ Sustainable development indicators measure changes in all these areas together, ie the effects of changes in one area, which are also recorded in the remaining areas. Sustainable development indicators can therefore be used in different tourist destinations or countries for different purposes. The indicators reflect the changes that are the result of cause-and-effect relationships in the environment.

\section{CONCLUSION}

Ecotourism implies conscientious travel in nature while preserving the environment and improving the living standards of the local population and is one of the most dynamic segments of the international travel industry. The basic principles of ecotourism are minimizing the negative impacts on nature and culture that can harm the destination, educating travelers about the importance of protection, direct income from protection and management of natural and protected areas. Research shows that the highest growth rate from year to year is recorded by the types of tourism associated with staying in pure untouched nature, with engaging in some form of recreation or extreme sports. New exotic destinations are being sought to be discovered and explored. Successful implementation of environmental components (environmental protection, giving preference to those products that are organized in accordance with environmental standards, etc.) in the future implementation of marketing activities in tourism is the basis on which to permanently build competitiveness in tourism. The development of tourism should emphasize the ecological, health, recreational values and specifics of the receptive space. Eco destinations attract modern tourists, giving them a sense of closeness to natural values and the local community, while protecting their resources. Ecotourism is an environmentally friendly journey, which emphasizes the observation and preservation of natural habitats and archaeological treasures, a means of environmental protection, environmentally responsible tourism, a way to protect natural areas that includes economic gain, through the protection of natural resources.

\section{REFERENCES}

[1] Bakić, O., (1993). Marketing menadžment turističke destinacije, Ekonomski fakultet, Beograd.

[2] World Tourist Organization, (2015), Voluntary Initiatives in Sustainable Tourism: Worldwide inventory and comparative analysis

[3] Vujović S., Cvijanović D., Štetić S., (2012), Destinacijski concept razvoja turizma, Monografija, Institut za ekonomiku poljoprivrede, Beograd

[4] Čekrlija Saša, (2017), Ekoturizam i održivo upravljanje resursima, SVAROG br. 14., DOI 10.7251/SVA1714227C

[5] Honey, M. (1999), Ecotourism and Sustainable Development: Who Owns Paradise?, Island Press

[6] Ross S., Wall G. (1999). Evaluating ecotourism: The case of North Sulawesi, Indonesia, Tourism Management, 20, 673-682.

[7] UNWTO, (2016), Tourism Highlights, Edition 2016

\section{AUTHORS}

First Author - Abdulwahab Tenish Phd,Candidate

\footnotetext{
${ }^{8}$ UNWTO, (2016), Tourism Highlights, Edition 2016.

This publication is licensed under Creative Commons Attribution CC BY 